\title{
Effect of Twist Drill Bit and Feeding Speed on Air Dust During Boring Process of Solid Wood and Wood-Based Composite Panels
}

\author{
Holta COTA ${ }^{1}$, Dritan AJDINAJ ${ }^{1}$, Entela LATO ${ }^{1}$, Zeki CANDAN ${ }^{2}$, Doklea QUKU ${ }^{1}$, Agron \\ BAJRAKTARI $^{3}$ and Süleyman KORKUT ${ }^{4 *}$
}

\footnotetext{
${ }^{1}$ Department of wood Industry, Faculty of Forestry Sciences, Agricultural University of Tirana, 1029, Tirana-Albania.

${ }^{2}$ Department of Forest Products Engineering, Faculty of Forestry, Istanbul University, 34473, Istanbul-Turkey.

${ }^{3}$ Prishtina University, Faculty of Technical Applied Sciences, 70000 Ferizaj, Kosovo.

${ }^{4}$ Department of Forest Products Engineering, Faculty of Forestry, Duzce University, 81620, Duzce-Turkey.
}

Accepted 15 February, 2012

\begin{abstract}
A study was carried out to analyze the particles produced during drilling process with twist drills with one and two spirals (length $70 \mathrm{~mm}$, diameter $8 \mathrm{~mm}$ ) with different feeding speeds, executed in beech (Fagus sylvatica), pine (Pinus sylvestris) and oak (Quercus petraea) woods, and also, medium density fiberboard (MDF), particleboard and poplar plywood panels. Drilling of solid woods was performed by following its longitudinal and transversal directions. The measurement and counting of wood dust particles was performed with a Particle Scan Pro instrument that measures the concentration of wood dust particles (milligrams per cubic meter or particles/l) present in the air. This instrument is able to count particles with diameter equal to and larger than $0.3 \mu \mathrm{m}$. A total of 281 tests were made with an average number of repetitions of eight for each material. The larger quantity of particles was produced by the wood-based panels, followed by hardwoods and finally, softwood. All drilled woods produced more particles on the longitudinal direction than on the transversal direction. For lower feeding speed, the number of particles increased with the increase of the number of bit's spirals. In general, the bits with one spiral produced a smaller number of pending particles than two spirals bits. Most of produced particles were registered in small sized categories $(\leq 1 \mu \mathrm{m} \varnothing)$, where most of them were occupied by micro fines particles with 0.3 to $0.5 \mu \mathrm{m}$ diameter, which were produced massively during $\mathrm{V}_{2} 2_{\mathrm{b}}$ work regime.
\end{abstract}

Key words: Twist drill bit, feeding speed, drilling process, dust particles, solid wood, wood composite panels.

\section{INTRODUCTION}

Wood dust appears as a serious problem, taking into consideration the number of people exposed continuously to it and the pathological effects caused from it. Furniture manufacturing industry represents the highest values of exposure, where only in EU countries 32 to $54 \%$ of workers are exposed to a level that reaches the value of $2 \mathrm{mg} / \mathrm{m}^{3}$ and more (Kauppinen et al., 2006). This fact becomes even more troubling considering the fact that this industry employs millions of people

\footnotetext{
*Corresponding author. E-mail: suleymankorkut@duzce.edu.tr.
}

worldwide (Lebedys, 2004) and the facts show that exposure to $1 \mathrm{mg} / \mathrm{m}^{3}$ causes irritation of mucous membrane (Borm et al., 2002), whereas, an exposure to over $1.5 \mathrm{mg} / \mathrm{m}^{3}$ cause damage to the clearance of the mucous membranes (Black et al., 1974; Wilhelmsson et al., 1984). Allergic symptoms to nasal region and sneezing are common to woodworkers especially to those who work with oak, beech, pine and some exotic species (Enarson and Chan-Yeung, 1990; Bohadana et al., 2000; Schlunssen, 2001). Symptoms that are related to the impairment of lung functions, to asthma, chronic bronchitis and cough, and also eye discomfort are significantly common among carpenters (Priha, 2004; 
Table 1. Properties of used materials.

\begin{tabular}{lcc}
\hline Materials & $\boldsymbol{\rho}\left(\mathbf{~ k ~ ~}^{-3}\right)$ & Moisture content $\mathbf{~ \% ) ~}$ \\
\hline Poplar plywood & 442 & 10.3 \\
Particleboard & 658 & 9.9 \\
MDF & 745 & 10.4 \\
Beech & 654 & 11.9 \\
Pine & 427 & 12.4 \\
Oak & 700 & 12.0 \\
\hline
\end{tabular}

Schlunssen, 2001).

The link between exposure to wood dust and sinonasal cancer in wood processing industry workers was identified in 1968 (Acheson et al., 1968) and many later subsequent studies and reports have reconfirmed this fact (Demers et al., 1995; Scientific Committee on Occupational Exposure Limits, 2003). However, now there is no doubt that wood dust is also able to cause DNA damage (U.S. Department of Health and Human Services, 2000; Lange, 2008). Based on this reality, International Agency for Research on Cancer (IARC) has made this classification of dust particles:

1. Group 1 (carcinogenic to man) - furniture manufacturing and cabinet making;

2. Group 2B (Possibly carcinogenic to man) - operations in wood processing enterprises and carpentry;

3. Group 3 (not classified as carcinogenic to man) production of lumber and sawn timber.

The amount of dust inhaled and deposited throughout the respiratory ways depends on the size, shape, solubility, chemical properties of surface, and density of dust particles, as well as from the strength (turbulence and velocity) of the air flow in the respiratory system (U.S. Environmental Protection Agency, 2004). Particles with diameter greater than $5 \mu \mathrm{m}$ ("inspirable" particles) are deposited almost completely in the nose, whereas those with diameter from 0.5 to $5 \mu \mathrm{m}$ ("respirable" particles) are deposited in the lower respiratory ways (U.S. Department of Health and Human Services, 2004) up to the lungs (fine particles) (Schlünssen et al., 2004). In fact, it is still unknown what the exact amount of dust that penetrates into the lower respiratory ways, but based on some measurements, some authors think that is about $10 \%$ of the total dust (Innocenti, 2008).

The total amount of wood dust produced and its particle sizes varies, depending on the type of machine (working operation) (Thorpe and Brown, 1994). In the quantity and characteristics of the dust, there are several factors combined together, such as, wood species (density and its anatomical structure) or the structure of processed wood-based composite panels [particleboard, medium density fiberboard (MDF), plywood, oriented strand board etc.], humidity of the material, direction of work in relation to wood's grain and also the processing machines. There are some elements that are included in the processing machine, such as, the type of cutting tool and the cuttingtool geometry, feeding speed and its cutting rate and depth of elaboration. Currently, the literature does not provide much information on the impact of these elements in the wood dust amount and its size.

This study presents the quantitative analysis (total assessment) and the size distribution (classification according to the diameter) of wood dust emitted during the drilling process in a working place environment. Analysis is performed in function of four factors: the cutting instrument (twist drills with 1 and 2 spirals), the feeding speed (two speeds are applied), the processed material (some types of wood and wood-based panels) and the operation's direction according the anatomic structure of wood. Boring is one of the main technological operations in furniture manufacturing, where the possibility to use cutting instruments (bits) with different technological parameters by the same machine is significant. For technical reasons, the study was focused on particles with diameter from 0.3 to $30 \mu \mathrm{m}$, classified in 6 size categories, three of which belong to the ultra fine particles with diameter $<1 \mu \mathrm{m}$.

\section{MATERIALS AND METHODS}

\section{Materials}

The study was carried out on materials (Table 1), which are commonly used as raw materials in the wood processing industry. Determination of moisture content (MC) and density for all materials were performed at the moment of testing.

The tests were carried out on boring machine "BORING SYSTEM 23" of "Maggi Engeniering" Company. This machine is designed to drill different wood materials like solid woods, MDF, particleboard, plywood panels etc., with different types of boring bits and different feeding rates. The holes were drilled by the twist drills with one and two canals, with a length of $70 \mathrm{~mm}$ and a diameter of $8 \mathrm{~mm}$.

The measurement of sawdust particles was carried out through a device called Particle Scan Pro, which measures the concentration of airborne particles, present in the air in $\left[\mathrm{mg} / \mathrm{m}^{3}\right]$. This device is able to count the particles from 0.3 to $30 \mu \mathrm{m}$ and divides them into

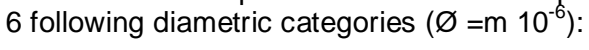

1) $0,3 \leq \varnothing \leq 0,5$

2) $0,5 \leq \varnothing \leq 0,7$

3) $0,7 \leq \varnothing \leq 1$

4) $1 \leq \varnothing \leq 2$ 
Table 2. Tests data variables.

\begin{tabular}{lll}
\hline & Description & Abbreviation \\
\hline \multirow{2}{*}{ Feed Rate } & Feeding speed $1 \mathrm{~m} \mathrm{~min}^{-1}$ & $\mathrm{~V}_{1}$ \\
& Feeding speed $2 \mathrm{~m} \mathrm{~min}^{-1}$ & $\mathrm{~V}_{2}$ \\
\hline \multirow{3}{*}{ Twist drill bits' type } & Diameter $8 \mathrm{~mm}$, length $70 \mathrm{~mm}$, one bit & $1_{\mathrm{b}}$ \\
& Diameter $8 \mathrm{~mm}$, length $70 \mathrm{~mm}$, two bits & $2_{\mathrm{b}}$ \\
\hline & Beech longitudinal direction & Beech-L \\
& Beech transversal direction & Beech-T \\
& Pine $(P$. sylvestris) longitudinal direction & Pine-L \\
Materials & Pine $(P$. sylvestris) transversal direction & Pine-T \\
& Oak longitudinal direction & Oak-L \\
& Oak transversal direction & Oak-T \\
& Medium Density Fiberboard & MDF \\
& Particleboard & Particleboard \\
Constant variables & Poplar Plywood & Plywood \\
Holes depth & & \\
Nr. rot/min of twist drill & 18 mm & \\
Drilling machine & 2800 RPM & \\
\hline
\end{tabular}

$$
\text { 5) } 2 \leq \varnothing \leq 5
$$

5) $5 \leq \varnothing \leq 30$

\section{Method of tests performing}

Non through-holes were bored applying two feeding rates $V_{1}=1$ $\mathrm{m} / \mathrm{min}$ and $V_{2}=2 \mathrm{~m} / \mathrm{min}$. These velocities were calculated by the formula $V=L / t$, where $L$ - the length of the way generated by the twist drill from the initial cutting, up to the depth of the hole and $t$-the needed time to cover this way. The depth of the holes had to be 18 $\mathrm{mm}$, which was controlled by the caliper. The holes of solid wood were bored following the longitudinal and transversal anatomical directions. The boring machine was leveled and the compressor was recharged to $7.5 \mathrm{Bar}$, before the work started. This pressure was controlled after each boring, in order for the pressure to be the same for each measurement (the machine works from 6 to 8 Bars). The defining of the data tests was carried out, in order to compare the boring processes and the essential parameters that affected in sawdust particles formation (Table 2).

\section{Procedures of test performance}

Before every test started, 10 air measurements were done with Particle Scan, in order to know the quantity of particles presented in the air. After getting all the tests results for all the samples of one material, from their maximum results, the average value of the first ten measurements of Particle Scan instrument was deducted. The difference is the true value of wood dust particles that the boring process gives in this case. This procedure is repeated for all executed tests. The Particle Scan instrument was positioned in the area where the operator usually stays. In this manner, the amount of particles that reaches up to him can be investigated. However, the obtained data appeared not homogeneous and not repetitive, because of microclimatic conditions effects (ascending air currents, operator's movements etc.). To make the environment less influential in the executed tests, it was decided that the instrument should be placed closer to the source of particles (Figure 1). In this case, the data obtained were much more homogeneous and repetitive, although not representing the numbers of particles that reach the operator, it offered the possibility to freely compare the different drilling instruments, materials and parameters of the processing. The Particle Scan's probe was positioned in the center of the four twist drills, of the boring machine (Figure 1).

In this study, 281 tests were carried out with an average number of repetitions of approximately 8 times (Table 3 ).

The data obtained from the measurements were processed in an MS Excel spreadsheet and the graphs were built according to the fractions of particles. These graphs provide data on the performance of the quantities of particles divided by fractions from the beginning of the tests up to the moment that the level of particles in the air reaches the initial state.

\section{RESULTS AND DISCUSSION}

The total dust particles and their percentage of size distribution produced by each wood-based composite panel during four boring regimes are summarized as follows (Tables 4, 5 and 6).

The six tables below summarize the results obtained during the four boring regimes of three studied wood species, taking into consideration their anatomical direction (Tables 7, 8, 9, 10, 11 and 12).

The studied materials, although worked with the same machine and the same work regime, produced different amounts of dust both in total as well as in size. This is confirmed the information given in literature (Thorpe and Brown, 1995).

From the obtained results, a classification for materials based on the number of particles produced for each work regime cannot be made. A classification, results only for the $V_{1} 2_{b}$ and $V_{2} 2_{b}$ work regimes where the multi-ply gives the most amount of produced particles, followed by MDF and particleboard and then by beech, oak and pine. It 


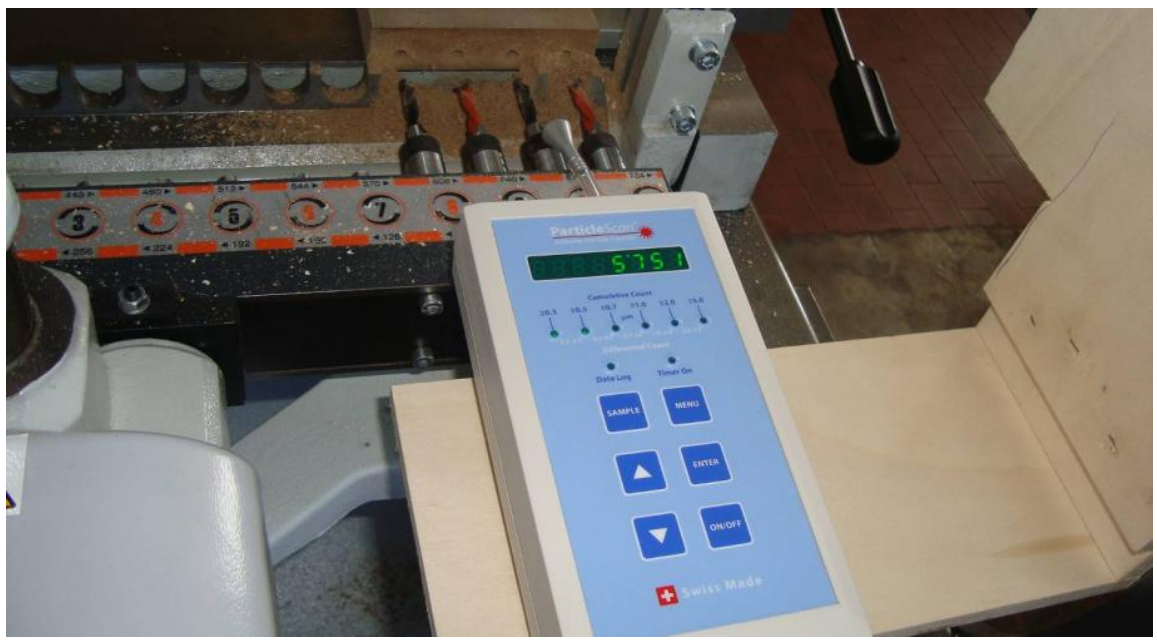

Figure 1. Placement of the particle measuring instrument closer to the source of particles, avoiding the environmental impacts.

Table 3. The number of tests performed for each material.

\begin{tabular}{|c|c|c|c|c|c|c|c|}
\hline \multicolumn{2}{|c|}{$V_{1} 1_{b}$} & \multicolumn{2}{|c|}{$V_{1} 2_{b}$} & \multicolumn{2}{|c|}{$V_{2} 1_{b}$} & \multicolumn{2}{|c|}{$V_{2} 2_{b}$} \\
\hline Material & Nr. tests & Material & Nr. tests & Material & Nr. tests & Material & Nr. tests \\
\hline MDF & 8 & MDF & 8 & MDF & 7 & MDF & 7 \\
\hline Particle-board & 8 & Particle-board & 8 & Particle-board & 9 & Particle-board & 8 \\
\hline Beech-L & 7 & Beech-L & 7 & Beech-L & 8 & Beech-L & 8 \\
\hline Beech-T & 8 & Beech-T & 8 & Beech-T & 8 & Beech-T & 8 \\
\hline Pine-L & 8 & Pine-L & 8 & Pine-L & 8 & Pine-L & 8 \\
\hline Pine-T & 9 & Pine- $T$ & 9 & Pine- $T$ & 8 & Pine-T & 8 \\
\hline Oak-L & 8 & Oak-L & 7 & Oak-L & 7 & Oak-L & 7 \\
\hline Oak-T & 8 & Oak-T & 7 & Oak-T & 8 & Oak-T & 7 \\
\hline Plywood & 8 & Plywood & 8 & Plywood & 8 & Plywood & 7 \\
\hline
\end{tabular}

Table 4. Total of dust particles and their size distribution during boring process of MDF.

\begin{tabular}{|c|c|c|c|c|c|c|c|c|c|c|c|c|c|}
\hline \multirow{3}{*}{$\begin{array}{l}\text { Boring } \\
\text { regime }\end{array}$} & \multirow{3}{*}{$\begin{array}{c}\text { Total of } \\
\text { particles }\end{array}$} & \multicolumn{12}{|c|}{ Size distributions } \\
\hline & & \multicolumn{2}{|c|}{$0.3-0.5$} & \multicolumn{2}{|c|}{$0.5-0.7$} & \multicolumn{2}{|c|}{$0.7-1$} & \multicolumn{2}{|c|}{$1.0-2.0$} & \multicolumn{2}{|c|}{$2.0-5.0$} & \multicolumn{2}{|c|}{$>5$} \\
\hline & & $\%$ & St. Dev. & $\%$ & St. Dev. & $\%$ & St. Dev. & $\%$ & St. Dev. & $\%$ & St. Dev. & $\%$ & St. Dev. \\
\hline $\mathrm{V}_{1} 1_{\mathrm{b}}$ & 302706 & 32.5 & 60615 & 8.9 & 10440 & 9.6 & 11072 & 6.0 & 6998 & 5.2 & 5959 & 37.8 & 44807 \\
\hline$V_{1} 2 b$ & 1581435 & 76.3 & 264082 & 10.3 & 47993 & 3.8 & 12721 & 1.4 & 997 & 1.1 & 2765 & 7.1 & 10914 \\
\hline $\mathrm{V}_{2} 1_{\mathrm{b}}$ & 72858 & 37.4 & 22642 & 10.3 & 6806 & 10.3 & 8637 & 5.3 & 4515 & 4.6 & 3619 & 32.0 & 25954 \\
\hline$V_{2} 2_{b}$ & 110173 & 79.6 & 56520 & 13.3 & 8960 & 2.5 & 880 & 1.0 & 448 & 0.8 & 471 & 2.6 & 972 \\
\hline
\end{tabular}

was noted that plywood panels MDF and particleboard drilled with $V_{1}$ feeding speed, with 2 spiral twist drills produced much more particles compared to the other three work regimes, as well as, woods studied.

If we refer only to wood-based panels, they are classified in three different variants for the four work regimes $\left(\mathrm{V}_{1} 1_{\mathrm{b}}\right.$-Plywood, Particleboard, MDF;
$\mathrm{V}_{2} 1_{\mathrm{b}}$-Particleboard, MDF, Plywood; $\mathrm{V}_{1} 2_{\mathrm{b}} \quad \& \quad \mathrm{~V}_{2} 2_{\mathrm{b}}$ Plywood, MDF, Particleboard).

On the other side, the classification of woods is presented in a different way, where we have the same classification (beech, oak and pine) for three work regimes, while in work regime $V_{2} 1_{b}$ the pine wood produces more particles than oak. For all regimes, the 
Table 5. Total of dust particles and their size distribution during boring process of particleboard.

\begin{tabular}{|c|c|c|c|c|c|c|c|c|c|c|c|c|c|}
\hline \multirow{3}{*}{$\begin{array}{l}\text { Boring } \\
\text { regime }\end{array}$} & \multirow{3}{*}{$\begin{array}{c}\text { Total of } \\
\text { particles }\end{array}$} & \multicolumn{12}{|c|}{ Size distributions } \\
\hline & & \multicolumn{2}{|c|}{$0.3-0.5$} & \multicolumn{2}{|c|}{$0.5-0.7$} & \multicolumn{2}{|c|}{$0.7-1$} & \multicolumn{2}{|c|}{$1.0-2.0$} & \multicolumn{2}{|c|}{$2.0-5.0$} & \multicolumn{2}{|c|}{$>5$} \\
\hline & & $\%$ & St. Dev. & $\%$ & St. Dev. & $\%$ & St. Dev. & $\%$ & St. Dev. & $\%$ & St. Dev. & $\%$ & St. Dev. \\
\hline$V_{1} 1_{b}$ & 625430 & 25.1 & 49593 & 19.2 & 29762 & 19.8 & 34790 & 10.0 & 15911 & 7.0 & 10177 & 19.0 & 26009 \\
\hline$V_{1} 2_{b}$ & 1455172 & 27.3 & 212541 & 17.9 & 105274 & 20.1 & 93142 & 9.9 & 32750 & 6.9 & 23290 & 17.9 & 51015 \\
\hline $\mathrm{V}_{2} 1_{\mathrm{b}}$ & 330327 & 30.8 & 109626 & 19.1 & 69460 & 18.0 & 76578 & 8.7 & 38645 & 6.0 & 26227 & 17.4 & 72452 \\
\hline$V_{2} 2 b$ & 86534 & 41.2 & 25584 & 23.7 & 13243 & 12.6 & 6346 & 5.0 & 2386 & 4.1 & 1491 & 13.4 & 5232 \\
\hline
\end{tabular}

Table 6. Total of dust particles and their size distribution during boring process of poplar plywood.

\begin{tabular}{|c|c|c|c|c|c|c|c|c|c|c|c|c|c|}
\hline \multirow{3}{*}{$\begin{array}{l}\text { Boring } \\
\text { regime }\end{array}$} & \multirow{3}{*}{$\begin{array}{l}\text { Total of } \\
\text { particles }\end{array}$} & \multicolumn{12}{|c|}{ Size distributions } \\
\hline & & \multicolumn{2}{|c|}{$0.3-0.5$} & \multicolumn{2}{|c|}{$0.5-0.7$} & \multicolumn{2}{|c|}{$0.7-1$} & \multicolumn{2}{|c|}{$1.0-2.0$} & \multicolumn{2}{|c|}{$2.0-5.0$} & \multicolumn{2}{|c|}{$>5$} \\
\hline & & $\%$ & St. Dev. & $\%$ & St. Dev. & $\%$ & St. Dev. & $\%$ & St. Dev. & $\%$ & St. Dev. & $\%$ & St. Dev. \\
\hline $\mathrm{V}_{1} 1_{\mathrm{b}}$ & 1037911 & 30.9 & 115555 & 22.2 & 81164 & 20.3 & 66650 & 8.4 & 25069 & 5.1 & 14209 & 13.1 & 32502 \\
\hline$V_{1} 2_{b}$ & 1597329 & 32.4 & 224032 & 19.2 & 113315 & 20.0 & 83358 & 8.8 & 35190 & 5.6 & 17838 & 13.9 & 42342 \\
\hline $\mathrm{V}_{2} 1_{\mathrm{b}}$ & 65466 & 43.0 & 19440 & 28.5 & 13414 & 14.2 & 5556 & 4.2 & 2379 & 3.1 & 1350 & 7.0 & 3474 \\
\hline$V_{2} 2 b$ & 125357 & 45.3 & 14072 & 26.9 & 7419 & 12.3 & 3345 & 4.6 & 1468 & 3.0 & 900 & 7.9 & 2217 \\
\hline
\end{tabular}

Table 7. Total of particles and their size distribution during boring process of Beech, longitudinal direction.

\begin{tabular}{|c|c|c|c|c|c|c|c|c|c|c|c|c|c|}
\hline \multirow{3}{*}{$\begin{array}{l}\text { Boring } \\
\text { regime }\end{array}$} & \multirow{3}{*}{$\begin{array}{l}\text { Total of } \\
\text { particles }\end{array}$} & \multicolumn{12}{|c|}{ Size distributions } \\
\hline & & \multicolumn{2}{|c|}{$0.3-0.5$} & \multicolumn{2}{|c|}{$0.5-0.7$} & \multicolumn{2}{|c|}{$0.7-1$} & \multicolumn{2}{|c|}{$1.0-2.0$} & \multicolumn{2}{|c|}{$2.0-5.0$} & \multicolumn{2}{|c|}{$>5$} \\
\hline & & $\%$ & St. Dev. & $\%$ & St. Dev. & $\%$ & St. Dev. & $\%$ & St. Dev. & $\%$ & St. Dev. & $\%$ & St. Dev. \\
\hline $\mathrm{V}_{1} 1$ & 730420 & 62.2 & 158595 & 12.1 & 17038 & 9.5 & 14977 & 4.4 & 8588 & 3.1 & 7617 & 8.7 & 21101 \\
\hline$V_{1} 2_{b}$ & 755326 & 29.8 & 66236 & 14.2 & 16469 & 16.9 & 22533 & 9.3 & 14445 & 7.0 & 12982 & 22.8 & 46312 \\
\hline $\mathrm{V}_{2} 1_{\mathrm{b}}$ & 288422 & 72.7 & 481319 & 11.7 & 81134 & 6.1 & 55525 & 2.9 & 24713 & 1.8 & 16521 & 4.8 & 39920 \\
\hline$V_{2} 2_{b}$ & 60659 & 77.6 & 22833 & 11.5 & 1898 & 4.5 & 719 & 1.8 & 361 & 1.3 & 300 & 3.4 & 667 \\
\hline
\end{tabular}

Table 8. Total of particles and their size distribution during boring process of Beech, transversal direction.

\begin{tabular}{|c|c|c|c|c|c|c|c|c|c|c|c|c|c|}
\hline \multirow{3}{*}{$\begin{array}{l}\text { Boring } \\
\text { regime }\end{array}$} & \multirow{3}{*}{$\begin{array}{l}\text { Total of } \\
\text { particles }\end{array}$} & \multicolumn{12}{|c|}{ Size distributions } \\
\hline & & \multicolumn{2}{|c|}{$0.3-0.5$} & \multicolumn{2}{|c|}{$0.5-0.7$} & \multicolumn{2}{|c|}{$0.7-1$} & \multicolumn{2}{|c|}{$1.0-2.0$} & \multicolumn{2}{|c|}{$2.0-5.0$} & \multicolumn{2}{|c|}{$>5$} \\
\hline & & $\%$ & St. Dev. & $\%$ & St. Dev. & $\%$ & St. Dev. & $\%$ & St. Dev. & $\%$ & St. Dev. & $\%$ & St. Dev. \\
\hline $\mathrm{V}_{1} 1_{\mathrm{b}}$ & 673853 & 21.9 & 66165 & 17.7 & 34883 & 22.2 & 41444 & 11.0 & 20706 & 6.9 & 13397 & 20.3 & 45915 \\
\hline$V_{1} 2_{b}$ & 736553 & 23.0 & 28700 & 17.0 & 27897 & 21.3 & 34854 & 10.7 & 17139 & 7.2 & 8871 & 20.8 & 23200 \\
\hline$V_{2} 1_{b}$ & 181612 & 27.9 & 54233 & 18.7 & 49195 & 18.2 & 57031 & 9.7 & 31863 & 6.7 & 21410 & 18.7 & 56324 \\
\hline$V_{2} 2_{b}$ & 33931 & 43.6 & 7419 & 20.5 & 972 & 11.0 & 732 & 5.8 & 933 & 4.6 & 799 & 14.5 & 1491 \\
\hline
\end{tabular}

three species of woods produce more particles in the longitudinal boring than in the transversal one. Referring to the total particles for the four work regimes taken together, the largest quantity of particles is produced by the wood-based panels, followed by hardwoods and at the end by the softwood (pine) (Table 13).

Regarding to the type of bit, it was noticed that for the
$V_{1}$ feed rate, the twist drill bits with two spirals produce more particles than that with one spiral regardless of material and direction of boring. Whereas, for the $V_{2}$ feed rate this relationship does not exist. So, for the small feed rate, the greater the number of spirals, the greater the number of particles produced is. It was noticed that despite the feeding rate, MDF, multiply and drilled oak 
Table 9. Total of particles and their size distribution during boring process of Oak, longitudinal direction.

\begin{tabular}{|c|c|c|c|c|c|c|c|c|c|c|c|c|c|}
\hline \multirow{3}{*}{$\begin{array}{l}\text { Boring } \\
\text { regime }\end{array}$} & \multirow{3}{*}{$\begin{array}{c}\text { Total of } \\
\text { particles }\end{array}$} & \multicolumn{12}{|c|}{ Size distributions } \\
\hline & & \multicolumn{2}{|c|}{$0.3-0.5$} & \multicolumn{2}{|c|}{$0.5-0.7$} & \multicolumn{2}{|c|}{$0.7-1$} & \multicolumn{2}{|c|}{$1.0-2.0$} & \multicolumn{2}{|c|}{$2.0-5.0$} & \multicolumn{2}{|c|}{$>5$} \\
\hline & & $\%$ & St. Dev. & $\%$ & St. Dev. & $\%$ & St. Dev. & $\%$ & St. Dev. & $\%$ & St. Dev. & $\%$ & St. Dev. \\
\hline$\overline{V_{1} 1}$ & 4 & 55.2 & 305341 & 19.8 & 61505 & 11.2 & 34330 & 4.1 & 11519 & 2.6 & 7037 & 7.1 & 19621 \\
\hline$V_{1} 2_{b}$ & 448008 & 43.0 & 128283 & 17.1 & 36810 & 12.8 & 25718 & 6.3 & 8935 & 4.4 & 6669 & 16.4 & 20882 \\
\hline$V_{2} 1_{b}$ & 17197 & 46.9 & 2919 & 30.1 & 1894 & 9.4 & 459 & 3.6 & 217 & 2.1 & 51 & 7.9 & 300 \\
\hline$V_{2} 2_{b}$ & 32482 & 63.2 & 14697 & 18.9 & 2993 & 6.9 & 378 & 2.0 & 499 & 2.9 & 511 & 6.1 & 1028 \\
\hline
\end{tabular}

Table 10. Total of particles and their size distribution during boring process of Oak, transversal direction.

\begin{tabular}{|c|c|c|c|c|c|c|c|c|c|c|c|c|c|}
\hline \multirow{3}{*}{$\begin{array}{l}\text { Boring } \\
\text { regime }\end{array}$} & \multirow{3}{*}{$\begin{array}{c}\text { Total of } \\
\text { particles }\end{array}$} & \multicolumn{12}{|c|}{ Size distributions } \\
\hline & & \multicolumn{2}{|c|}{$0.3-0.5$} & \multicolumn{2}{|c|}{$0.5-0.7$} & \multicolumn{2}{|c|}{$0.7-1$} & \multicolumn{2}{|c|}{$1.0-2.0$} & \multicolumn{2}{|c|}{$2.0-5.0$} & \multicolumn{2}{|c|}{$>5$} \\
\hline & & $\%$ & St. Dev. & $\%$ & St. Dev. & $\%$ & St. Dev. & $\%$ & St. Dev. & $\%$ & St. Dev. & $\%$ & St. Dev. \\
\hline $\mathrm{V}_{1} 1$ & 3 & 21.0 & 8013 & 23.6 & 13517 & 23.0 & 17413 & 10.5 & 10285 & 6.5 & 8125 & 15.4 & 15414 \\
\hline$V_{1} 2_{b}$ & 343281 & 26.3 & 39387 & 21.8 & 21965 & 21.5 & 26345 & 9.5 & 9900 & 6.0 & 7865 & 14.9 & 19882 \\
\hline $\mathrm{V}_{2} 1_{\mathrm{b}}$ & 15016 & 45.0 & 4898 & 25.6 & 2278 & 10.6 & 1032 & 4.7 & 529 & 3.4 & 240 & 10.7 & 691 \\
\hline$V_{2} 2_{b}$ & 22646 & 49.8 & 10103 & 24.9 & 1357 & 8.3 & 1127 & 4.2 & 582 & 3.6 & 471 & 9.3 & 728 \\
\hline
\end{tabular}

Table 11. Total of particles and their size distribution during boring process of Pine, longitudinal direction.

\begin{tabular}{|c|c|c|c|c|c|c|c|c|c|c|c|c|c|}
\hline \multirow{3}{*}{$\begin{array}{l}\text { Boring } \\
\text { regime }\end{array}$} & \multirow{3}{*}{$\begin{array}{c}\text { Total of } \\
\text { particles }\end{array}$} & \multicolumn{12}{|c|}{ Size distributions } \\
\hline & & \multicolumn{2}{|c|}{$0.3-0.5$} & \multicolumn{2}{|c|}{$0.5-0.7$} & \multicolumn{2}{|c|}{$0.7-1$} & \multicolumn{2}{|c|}{$1.0-2.0$} & \multicolumn{2}{|c|}{$2.0-5.0$} & \multicolumn{2}{|c|}{$>5$} \\
\hline & & $\%$ & St. Dev. & $\%$ & St. Dev. & $\%$ & St. Dev. & $\%$ & St. Dev. & $\%$ & St. Dev. & $\%$ & St. Dev. \\
\hline $\mathrm{V}_{1} 1_{\mathrm{b}}$ & 60483 & 39.5 & 8697 & 26.1 & 9645 & 15.3 & 6236 & 6.0 & 2194 & 3.5 & 1119 & 9.6 & 2480 \\
\hline$V_{1} 2_{b}$ & 67757 & 52.0 & 19630 & 16.6 & 2076 & 12.3 & 2943 & 5.9 & 802 & 3.2 & 734 & 10.0 & 2180 \\
\hline$V_{2} 1_{b}$ & 30988 & 36.7 & 6349 & 23.4 & 5510 & 12.2 & 3229 & 6.4 & 1641 & 3.9 & 982 & 17.4 & 4578 \\
\hline$V_{2} 2_{b}$ & 9392 & 60.4 & 1225 & 24.6 & 254 & 8.9 & 261 & 2.3 & 96 & 1.3 & 67 & 2.5 & 86 \\
\hline
\end{tabular}

Table 12. Total of particles and their size distribution during boring process of Pine, transversal direction.

\begin{tabular}{|c|c|c|c|c|c|c|c|c|c|c|c|c|c|}
\hline \multirow{3}{*}{$\begin{array}{l}\text { Boring } \\
\text { regime }\end{array}$} & \multirow{3}{*}{$\begin{array}{c}\text { Total of } \\
\text { particles }\end{array}$} & \multicolumn{12}{|c|}{ Size distributions } \\
\hline & & \multicolumn{2}{|c|}{$0.3-0.5$} & \multicolumn{2}{|c|}{$0.5-0.7$} & \multicolumn{2}{|c|}{$0.7-1$} & \multicolumn{2}{|c|}{$1.0-2.0$} & \multicolumn{2}{|c|}{$2.0-5.0$} & \multicolumn{2}{|c|}{$>5$} \\
\hline & & $\%$ & St. Dev. & $\%$ & St. Dev. & $\%$ & St. Dev. & $\%$ & St. Dev. & $\%$ & St. Dev. & $\%$ & St. Dev. \\
\hline$V_{1} 1_{b}$ & 30074 & 43.5 & 8013 & 22.4 & 13517 & 11.0 & 17413 & 4.5 & 10285 & 3.1 & 8125 & 15.5 & 15414 \\
\hline $\mathrm{V}_{1} 2_{\mathrm{b}}$ & 57907 & 59.6 & 39387 & 18.0 & 21965 & 7.3 & 26345 & 3.8 & 9900 & 2.6 & 7865 & 8.8 & 19882 \\
\hline $\mathrm{V}_{2} 1_{\mathrm{b}}$ & 18649 & 46.7 & 4898 & 20.7 & 2278 & 11.6 & 1032 & 5.8 & 529 & 4.2 & 240 & 10.9 & 691 \\
\hline$V_{2} 2_{b}$ & 8479 & 57.6 & 10103 & 23.6 & 1357 & 8.1 & 1127 & 3.7 & 582 & 2.9 & 471 & 4.1 & 728 \\
\hline
\end{tabular}

according to both its anatomical directions, produce more particles with the increasing number of bit's spirals. This is not observed in particleboard and the other two drilled woods according to both their anatomical directions, which for the $V_{2}$ feeding rate produce more particles with one spiral. By considering the general average of particles produced with the $V_{1}$ and $V_{2}$ feeding rate, it was noted that the 1 spiral twist drill bit produces a smaller number of pending particles than the two spirals twist drill bit (Figure 2). This bit produces $40 \%$ of the overall total particles.

Regardless of material type, number of bit's spirals and direction of boring, the largest amount of particles is produced by the $\mathrm{V}_{1}$ feeding rate, and also for small feed 
Table 13. The total quantity of particles produced by the materials.

\begin{tabular}{clc}
\hline No. & Material & $\begin{array}{c}\text { Total particles produced } \\
\text { for the four works regimes }\end{array}$ \\
\hline 1 & Poplar multi-ply & 2826063 \\
2 & Particleboard & 2497463 \\
3 & MDF & 2067172 \\
4 & Beech longitudinal & 1634827 \\
5 & Beech transversal & 1625949 \\
6 & Oak longitudinal & 903468 \\
7 & Oak transversal & 609536 \\
8 & Pine longitudinal & 148620 \\
9 & Pine transversal & 115109 \\
\hline
\end{tabular}

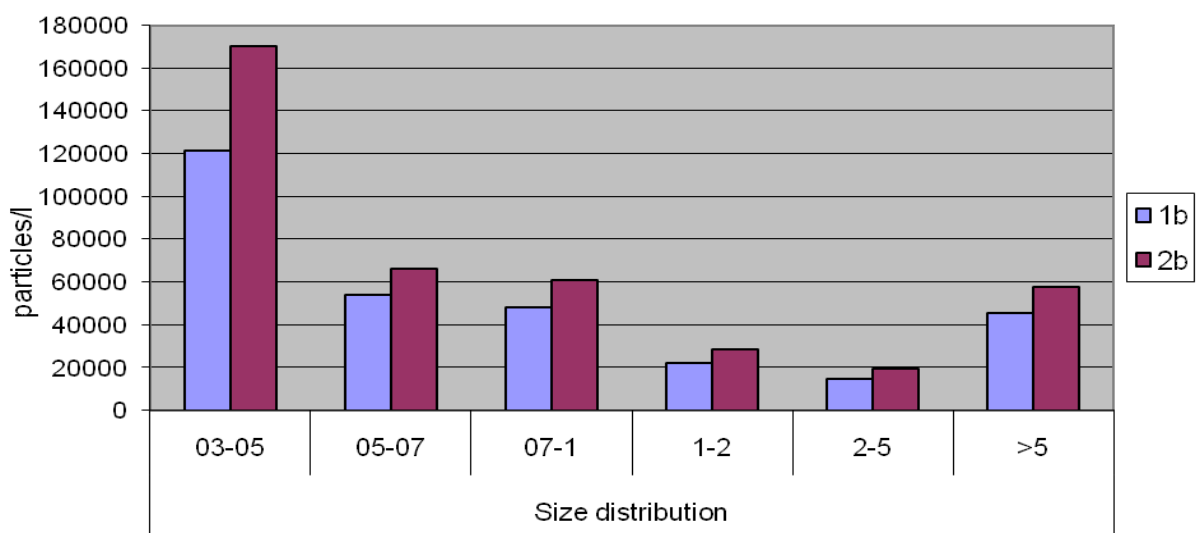

Figure 2. Particle size distribution referring to number of bits.

Table 14. Ratio of particles diametric classes produced by drilling with $V_{1}$ and $V_{2}$ feeding rate.

\begin{tabular}{lcccccc}
\hline \multirow{2}{*}{ Rapport } & \multicolumn{7}{c}{ Size distribution } \\
\cline { 2 - 7 } & $\mathbf{0 . 3 - 0 . 5}$ & $\mathbf{0 5 - \mathbf { 0 . 7 }}$ & $\mathbf{0 . 7 - 1}$ & $\mathbf{1 - 2}$ & $\mathbf{2 - 5}$ & $>\mathbf{5}$ \\
\hline $\mathrm{V}_{1} / \mathrm{V}_{2}$ & 5.9 & 6.8 & 10.1 & 10.3 & 9.8 & 9.5 \\
\hline
\end{tabular}

speeds. The amount of particles produced during the boring of the $V_{1}$ feeding rate represents $88 \%$ of the total number of particles generated, versus only $12 \%$ of the $V_{2}$ feeding rate. The ratio of diametric classes for particles produced at $V_{1}$ and $V_{2}$ feeding rate results from 5.9 up to 10.3 (Table 14).

For all materials considered in this study, the variant which produces more particles is $\mathrm{V}_{1} 2_{\mathrm{b}}$. This is particularly noticed in wood-based panels and especially in MDF, which for this work regimen produces $76 \%$ of the total amount of particles. This regime produces $52 \%$ of the total number of particles for all size classes, followed by $\mathrm{V}_{1} 1_{\mathrm{b}}$ with $34 \%, \mathrm{~V}_{2} 1_{\mathrm{b}}$ with $9 \%$ and finally $\mathrm{V}_{2} 2_{\mathrm{b}}$ by $5 \%$. Low feeding rate causes decrease in the chip's thickness, which brings a greater fragmentation of it and therefore an increase in generated particles. Chips fragmentation increases with the increase of the number of bits' cutting edges because the particles produced go easily through two spirals compare to one spiral twist drill bits. So, we can say that for low feeding rate and a large number of spirals of twist drill, more particles are produced. The average distribution of size particles calculated on the sum of the results obtained for all materials and boring regimes shows that the majority of particles is registered for the small size distribution $(\leq 1 \mu \mathrm{m} \varnothing)$ (Figure 3). Standard deviations (shown by error bars) show the overall performance of frequencies for size distribution, apart from high variability of data.

With the increasing diameter of particles, their percentage for the diametric classes decreases 


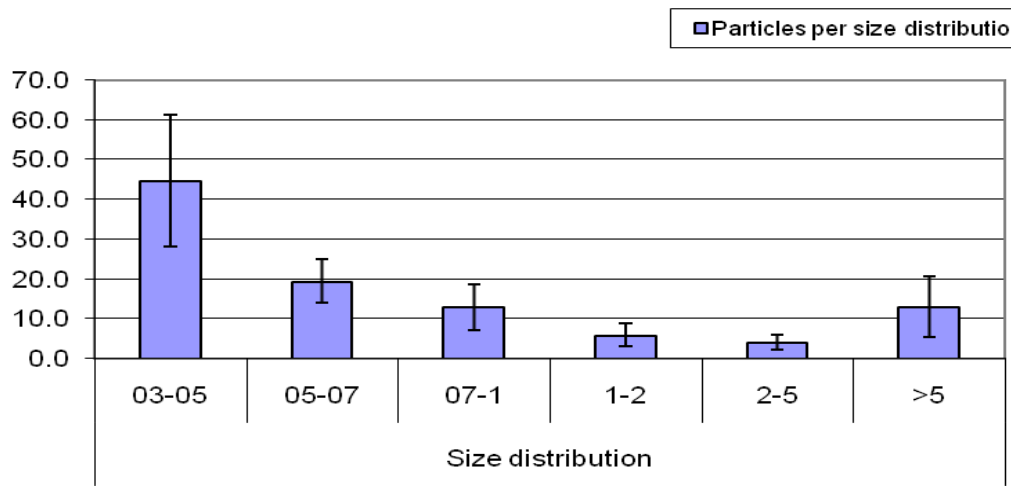

Figure 3. The average size distribution of dust particles referring to all tests.

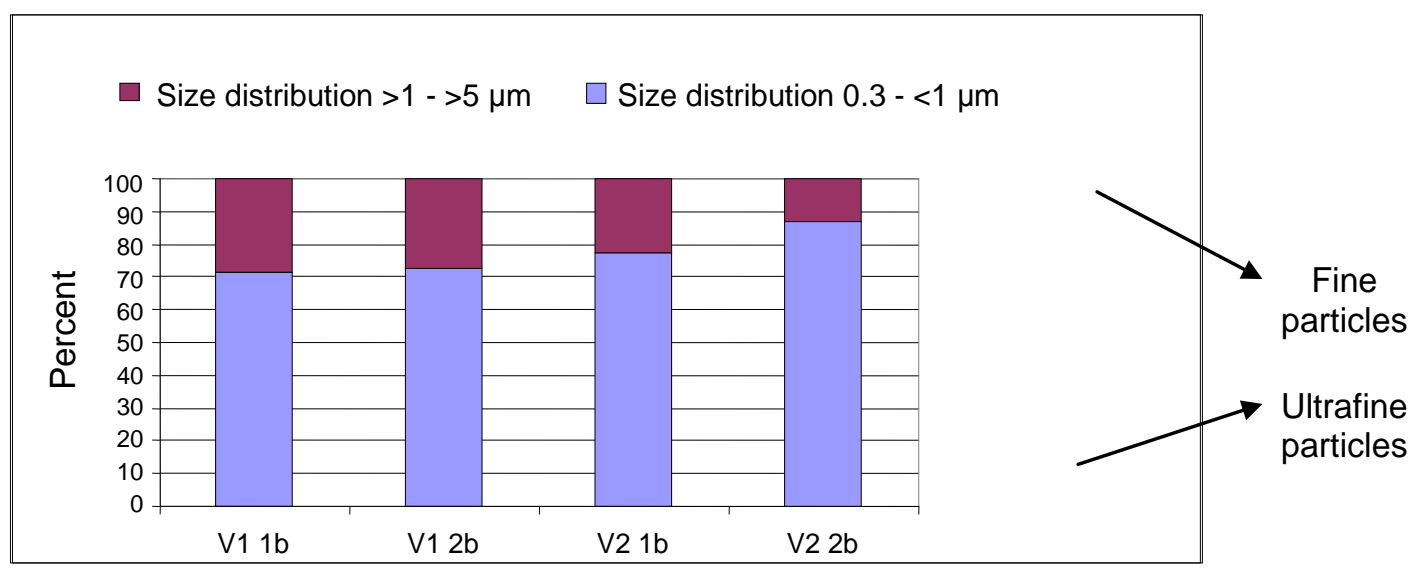

Figure 4. Distribution into fine and ultrafine particles referring to boring regimens.

continuously up to 2 to $5 \mu \mathrm{m}$ class, and increase again to $>5 \mu \mathrm{m}$ class. One such phenomenon is related to the fact that the instrument is able to measure up to a maximum diameter of $30 \mu \mathrm{m}$, and thus, the grouping made for the 5 to $30 \mu \mathrm{m}$ class turns out to be large enough. The highest percentage of particles for all boring regimens is for particles with 0.3 to $0.5 \mu \mathrm{m}$ diameter. Referring to this diametric group, the largest amount was given by $\mathrm{V}_{2} 2_{\mathrm{b}}$ regimen for all materials, except of pine in transversal direction, where $\mathrm{V}_{2} 2_{\mathrm{b}}$ regimen produces $2 \%$ less particles than $\mathrm{V}_{1} 2_{\mathrm{b}}$ regimen. For other diametric classes, there is no functional relationship as regard the boring regime. The maximum concentration of particles was from fine diametric classes and this was noticed for the four boring regimen (Figure 4). Ultra fine particles with diameter less than $1 \mu \mathrm{m}$, which penetrate in the lungs (Schlünssen et al., 2004), occupy $77 \%$ of the overall total, and those other ones with diameter greater than $1 \mu \mathrm{m}$ are only $23 \%$. This result differs from previous literature data, which the particles of 1 to $5 \mu \mathrm{m}$ diametric groups was placed at the level of 61 to $65 \%$ (International Agency for Research on Cancer, 1995).
For the four boring regimes, the size distribution curves are more or less the same, so the relationship between the size classes can be considered approximately the same (Figure 5).

Regarding the pending times of particles in air, it was noticed that in all cases, the amount of particles in the air returned into initial values before the boring process, indicating that the particles produced were deposited quickly or they were moved into space by moving away. The average periods in which these quantities of particles returned to the initial state of the evidence, were very fast (11 seconds) and more homogeneous (standard deviation $2.2 \mathrm{~s}$ ).

\section{Conclusion}

The executed tests provide only a part of the necessary information to assess the levels of wood particles during the manufacturing of wood furniture. It was observed that different materials gave different amounts of dust in total; and in the size distributions, during the boring, within the 


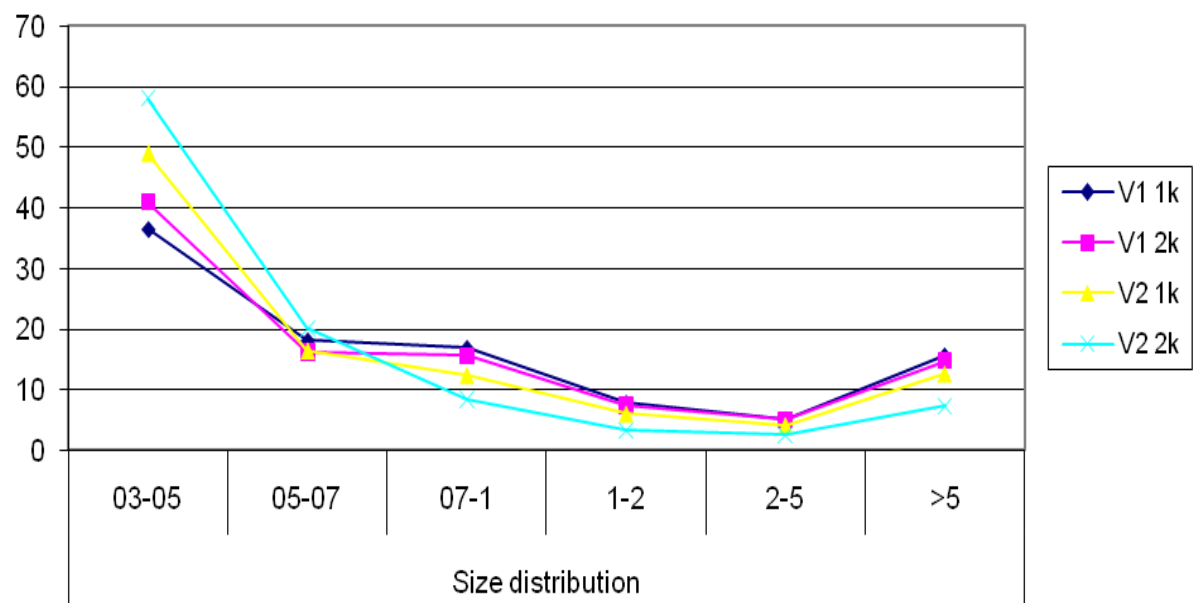

Figure 5. Size distribution of dust particles referring to boring regimens.

same regimen of process. The largest amounts of particles are produced by the wood-based panels, followed by hardwoods and by softwood at the end. Average periods in which the amount of pending particles returns to the initial state of tests are more rapid and more homogeneous. Woods produce more particles in longitudinal boring rather than in transversal boring direction. For the lower the feeding rate, the greater the number of bits' spiral, the greater the number of particles that is produced too. In general, the bit with one spiral produces a smaller number of pending particles than two spiral bits. Regardless of type of material, number of bits' spirals and boring direction, the largest amount of particles is produced by low feeding rate. For all studied materials, the variant that produces more particles is $\mathrm{V}_{1} 2_{\mathrm{b}}$, especially for wood-based panels. Most of the particles produced are registered in small sized classes $(\leq 1 \mu \mathrm{m} \varnothing)$, where most of them fall between the range of 0.3 to $0.5 \mu \mathrm{m}$ diameter, which were produced massively in $\mathrm{V}_{2} 2_{\mathrm{b}}$ regimen.

\section{REFERENCES}

Acheson ED, Cowdell RH, Hadfield E, Macbeth RG (1968). Nasal cancer in woodworkers in the furniture industry. Brit. Med. J., 2: 587596.

Black A, Evans JC, Hadfield EH, Macbeth RG, Morgan A, Walsh M (1974). Impairment of nasal mucociliary clearance in woodworkers in the furniture industry. Brit. J.Ind. Med., 31(1): 10-17.

Bohadana AB, Massin N, Wild P, Toamain JP, Engel S, Goutet P (2000). Symptoms, airway responsiveness and exposure to dust in beech and oak wood exposure. J. Occup. Environ. Med., 57(4): 268273.

Borm PJA, Jetten M, Hidayat S, van de Burgh N, Leunissen P, Kant I, Houba R, Soeprapto H (2002). Respiratory symptoms, lung function and nasal cellularity in Indonesian wood workers: a dose-response analysis. J. Occup. Environ. Med., 59(5): 338-344.

Demers PA, Kogevinas M, Boffetta P, Leclerc A, Luce D, Gérin M, Battista G, Belli S, Bolm-Audorf U, Brinton LA, Colin D, Comba P, Hardell L, Hayes RB, Magnani C, Merler E, Morcet JF, PrestonMartin S, Matos E, Rodella S, Vaughan TL, Zheng W, Vainio H
(1995). Wood dust and sino-nasal cancer: Pooled reanalysis of twelve case-control studies. Am. J. Ind. Med., 28(2): 151-166.

Enarson DA, Chan-Yeung M (1990). Characterization of health effects of wood dust exposures. Am. J. Ind. Med., 17(1): 33-38.

Innocenti A (2008). Health effects in wood dust: the respiratory function. Volume Of Acts: Wood Dust: Health and Safety, May, Como, Italy, p. 27-36.

International Agency for Research on Cancer (1995). IARC Monographs on the Evaluation of Carcinogenic Risks to Humans: Volume 62, Wood Dust and Formaldehyde. World Health Organization, Lyon, France, p. 405.

Kauppinen T, Vincent R, Liukkonen T, Grzebyk M, Kauppinen A, Welling I, Arezes P, Black N, Bochmann F, Campelo F, Costa M, Elsigan G, Goerens R, Kikemenis A, Kromhout H, Miguel S, Mirabelli $D$, Mceneany $R$, Pesch $B$, Plato $N$, Schlünssen V, Schulze J, Sonntag R, Verougstraete V, De Vicente MA, Wolf J, Zimmermann M, Husgafvel-Pursiainen K, Savolainen K (2006). Occupational exposure to inhalable wood dust in the member states of the European Union. Ann. Occup. Hyg., 50(6): 549-561.

Lange BJ (2008). Effects of Wood Dust: Inflammation, Genotoxicity and Cancer, PhD thesis. National Research Centre for the Working Environment of Copenhagen, Faculty of Health Sciences, p. 110.

Lebedys A (2004). Trends and current status of the contribution of the forestry sector to national economies. Working Paper: FSFM/ACC/07. Food and Agriculture Organization of the United Nations. Ref Type: Report.

Priha E, Pennanen S, Rantio T, Uitti J, Liesivuori J (2004). Exposure to and acute effects of medium-density fiber board dust. J. Occup. Environ. Hyg., 1(11): 738-744.

Scientific Committee on Occupational Exposure Limits (2003). Recommendation from the Scientific Committee on Occupational Exposure Limits: SCOEL/SUM/102 final. RefType: Report.

Schlunssen V (2001). Asthma and other respiratory diseases among workers in the Danish furniture Industry occupationally exposed to wood dust. Environmental and occupational department, Skive Hospital and Department of Environmental and Occupational Medicine, Aarhus University; http://ntpserver.niehs.nih.gov/newhomeroc/roc10/WD.pdf.

Schlünssen V, Kauppinen T, Vincent R, Liukkonen T, Grzebyk M. Kauppinen (2004). A Occupational exposure to wood dust in Denmark. Helsinki and Nancy, Finnish Institute of Occupational Health $(\mathrm{FIOH})$ and Institute of National de Recherche et de Sécurité (INRS). WOODEX by WOOD RISK project QLK4-2000-00573. RefType: Report.

Schlunssen V, Schaumburg I, Heederik D, Taudorf E, Sigsgaard T (2004). Indices of asthma among atopic and non-atopic woodworkers. J. Occup. Environ. Med., 61(6): 504-511. 
Thorpe A, Brown RC (1994). Measurements of the effectiveness of dust extraction systems of hand sanders used on wood. Ann. Occup. Hyg., 38(3): 279-302.

Thorpe A, Brown RC (1995). Factors influencing the production of dust during the hand sanding of wood. Am. Ind. Hyg. Assoc. J., 56(3): 236-242.

U.S.Department of Health and Human Services (2000). Final Report on Carcinogens, Background Document for Wood Dust. Meeting of the NTP Board of Scientific Counselors, Report on Carcinogens Subcommittee. RefType: Report.

U.S.Department of Health and Human Services (2004). 11th Report on Carcinogens (RoC), National Toxicology Program (NTP). RefType: Report.
U.S.Environmental Protection Agency (2004). Air Quality Criteria for Particulate Matter, Vol. II.EPA/600/P-99/002bF, Research Triangle Park, NC, U.S.Environmental Protection Agency. RefType: Report, p. 1148.

Wilhelmsson B, Drettner B (1984). Nasal problems in wood furniture workers. A study of symptoms and physiological variables. United States National Library of Medicine [PubMed], Acta Otolaryngol. NovDec., 98(5-6): 548-555. 